At-Tijaroh : Jurnal Ilmu Manajemen dan Bisnis Islam

Volume 5 Nomor 1 Ed. Jan - Juni 2019 : Hal -

p-ISSN : 2356-492x

e-ISSN : 2549-9270

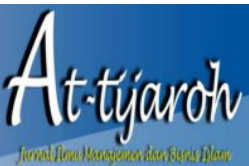

\title{
ANALISIS SIMULTAN KOMITMEN ORGANISASIONAL DAN ORGANIZATIONAL CITIZENSHIP BEHAVIOR TERHADAP KINERJA KARYAWAN
}

\author{
Moh Rifqi Kairul Umam¹, Samino Setiawan² \\ ${ }^{1}$ Institut Agama Islam Negeri Surakarta \\ 2 Universitas Islam Negeri Sunan Kalijaga Yogyakarta \\ ${ }^{1}$ Jl. Pandawa, Dusun IV, Puncangan, Sukoharjo, Jawa Tengah \\ 2Jl. Laksda Adisucipto, Papringan, Catur Tunggal, Sleman, D.I. Yogyakarta \\ ${ }^{1}$ moh.rifqi@iain-surakarta.ac.id \\ ²rifqi.elkhoiry@gmail.com
}

\begin{abstract}
Good employee commitment is reflected in its performance, while the ones that influence it are organizational commitment and organizational citizenship behavior. This study aims to determine the effect of organizational commitment on employee performance and $O C B$, the effect of $O C B$ on organizational commitment, and the influence of OCB on employee performance. The sample of this study was 300 people P.T. XYZ obtained by simple random sampling technique. The data analysis in this study uses the Structural Equation Modeling (SEM) analysis method which is operated through IBM AMOS Graphics 21 program. The analysis technique used in this study is the measurement model and structural model. The results showed organizational commitment had a significant positive effect on $O C B, O C B$ had a significant positive effect on organizational commitment, organizational commitment had a significant positive influence on employee performance, and $O C B$ had a significant positive effect on employee performance. The OCB as an intervening variable in the causality relationship between organizational commitment and employee performance has no significant effect. Organizational commitment as an intervening variable in the causality relationship between $O C B$ and employee performance also has no significant influence.
\end{abstract}

Keyword : Organizational Commitment, Organizational Citizenship Behavior, Employee Performance

\begin{abstract}
Abstrak
Komitmen karyawan yang baik tercermin dari kinerjanya, adapun yang memengaruhinya adalah komitmen organisasional dan organizational citizenship behavior. Penelitian ini bertujuan untuk mengetahui pengaruh komitmen organisasional terhadap kinerja karyawan dan OCB, pengaruh OCB terhadap komitmen organisasional, dan pengaruh OCB terhadap kinerja karyawan. Sampel penelitian ini sebanyak 300 orang karyawan P.T. XYZ yang diperoleh dengan teknik simple random sampling. Analisis data dalam penelitian ini menggunakan metode analisis Structural Equation Modelling (SEM) yang dioperasikan melalui program IBM AMOS Graphics 21. Teknik analisis yang digunakan dalam penelitian ini adalah model pengukuran (measurement model) dan model struktural (structural model). Hasil penelitian menunjukkan komitmen organisasional memiliki pengaruh positif signifikan terhadap OCB, OCB memiliki pengaruh positif signifikan terhadap komitmen organisasional, komitmen organisasional memiliki pengaruh positif signifikan terhadap kinerja karyawan, dan OCB memiliki pengaruh positif signifikan terhadap kinerja karyawan.
\end{abstract}




\section{7 | Analisis Simultan Komitmen Organisasional dan Organizational Citizenship Behavior Terhadap Kinerja Karyawan}

Adapun OCB sebagai variabel intervening pada hubungan kausalitas antara komitmen organisasional dengan kinerja karyawan tidak memiliki pengaruh signifikan. Komitmen organisasional sebagai variabel intervening pada hubungan kausalitas antara OCB dengan kinerja karyawan juga tidak memiliki pengaruh signifikan.

Kata Kunci: Komitmen Organisasional, Organizational Citizenship Behavior, Kinerja Karyawan

\section{PENDAHULUAN}

Keberhasilan pengelolaan organisasi selalu terkait dengan pemberdayagunaan sumber daya manusia (Handoko, 1989), sedangkan manajemen sumber daya manusia berkaitan dengan praktik dan keputusan manajer yang secara langsung dapat mempengaruhi sumber daya manusia (Simamora, 2001). Komitmen karyawan yang baik dalam berorganisasi dapat ditunjukkan dengan lebih produktif dalam bekerja, dimana indikatornya dapat dilihat dari kinerja yang dicapai. Komitmen organisasional merupakan keadaan dimana karyawan mengidentifikasi sebuah organisasi, tujuan, dan harapanya untuk tetap berada dalam organisasi(Robbins \& Judge, 2008).

Sebagian hasil penelitian menunjukkan tidak adanya hubungan yang signifikan antara komitmen organisasional dengan kinerja karyawan (Ellinger et al., 2013; Novita, Sunuharjo, \& Ruhana, 2016; Yiing \& Zaman, 2009), namun sebagian hasil penelitian lainnya menunjukkan hubungan yang signifikan (Nurmatias, 2015; Taurisa \& Ratnawati, 2012). Oleh karena itu, penelitian ini dilakukan berdasarkan kesenjangan hasil penelitian terdahulu dalam hubungan sebab akibat antara komitmen organisasional dengan kinerja karyawan, dimana terdapat inkonsistensi pada hasil penelitian-penelitian tersebut.

Faktor lain yang mempengaruhi kirnerja karyawan adalah Organizational Citizenship Behavior (OCB). OCB berpengaruh posisif dan signifikan terhadap kinerja karyawan (Darto, 2014; Harwiki, 2016; Nursyamsi, 2013; Supriyanto, 2013). Komitmen organisasional berpengaruh positif signifikan terhadap OCB (Nadim, Hassan, Abbas, \& Naveed, 2016; Sjahruddin, Armanu, Sudiro, \& Normijati, 2013; Supriyanto, 2013), dan sebaliknya, OCB juga berhubungan positif dan signifikan terhadap komitmen organisasional (Nursyamsi, 2013).

Dari uraian di atas, penelitian ini bertujuan untuk menguji hubungan pengaruh antara komitmen organisasional terhadap OCB, dan OCB terhadap komitmen organisasional, serta sekaligus menguji hubungan pengaruh antara komitmen organisasional dan OCB terhadap kinerja karyawan. Penelitian ini dilakukan dengan menggunakan beberapa asumsi dasar dari Theory of Planned Behavior (TPB) atau Teori Perilaku Terencana, yang merupakan pengembangan dari Theory of Reasoned Action (TRA) (Werner, 2004). TRA dirumuskan 
pada tahun 1967 untuk menguji konsistensi hubungan antara perilaku dan sikap (Fishbein \& Ajzen, 1975; Werner, 2004). TRA dan TPB berasumsi bahwa tindakan yang dilakukan seseorang berdasarkan rasionalitas, dimana seseorang akan mempertimbangkan secara rasional terkait dengan implikasi tindakan yang akan dilakukan.

\section{TINJAUAN TEORITIS}

\subsection{Kinerja Karyawan}

Kinerja berasal dari kata job performance atau actual performance, dan kinerja merupakan hasil kerja secara kualitas maupun kuantitas yang dicapai oleh seseorang karyawan dalam melaksanakan tugas sesuai dengan tanggung jawabnya (Mangkunegara \& Anwar, 2001). Kinerja karyawan juga merupakan perilaku ditampilkan karyawan sebagai prestasi kerja yang dihasilkan oleh karyawan tersebut sesuai dengan perannya dalam perusahaan (Zainal, Basalamah, dan Muhammad, 2014: 413). Christine, Oktorina, \& Mula (2010) menyatakan kinerja adalah pencapaian suatu hasil yang dikarakteristikan dengan keahlian tugas seseorang ataupun kelompok atas dasar tujuan yang telah ditetapkan. Mathis \& Jackson (2002) menyatakan bahwa standar kinerja seseorang dapat dilihat dari kualitas output, kuantitas output, jangka waktu output, kehadiran di tempat kerja, dan sikap kooperatif.

Kinerja merupakan perwujudan kerja yang dilakukan oleh karyawan yang biasanya dipakai sebagai dasar penilaian terhadap karyawan atau organisasi (Hasibuan, 2011). Wiedower (dalam Fayyaz, 2014) membagi indikator kinerja karyawan yang dinamakan dengan Employee Job Performance Scale menjadi lima indikator, yaitu ketepatan waktu, kualitas kerja, kuantitas kerja, kebutuhan supervisi, pengaruh hubungan interpersonal.

\subsection{Komitmen Organisasional}

Komitmen adalah kondisi psikologis yang mencirikan hubungan antara karyawan dengan organisasi dan memiliki implikasi bagi keputusan individu untuk tetap berada atau meninggalkan organisasi (Nurmatias, 2015). Sedangkan menurut Robbins dan Judge (2008) komitmen organisasional merupakan suatu keadaan dimana seorang karyawan memihak organisasi tertentu serta tujuan-tujuan dan keinginannya untuk mempertahankan keanggotaan dalam organisasi tersebut, sehingga keterlibatan pekerjaan yang tinggi berimplikasi pada pemihakan diri pada pekerjaan tertentu, sementara komitmen organisasi yang tinggi berarti memihak organisasi yang merekrut individu tersebut.

Hulin (1998) mengemukakan bahwa komitmen organisasi merupakan sikap ketertarikan terhadap organisasi secara menyeluruh, bukan sekedar karena peran dan tugas, serta mempertahankan dirinya agar tetap berada di dalam organisasi itu. Menurut Aktami (2008) karyawan dengan komitmen organisasi yang baik, ditunjukkan oleh sikap kerja yang 


\section{9 | Analisis Simultan Komitmen Organisasional dan Organizational Citizenship Behavior Terhadap Kinerja Karyawan}

penuh perhatian dan memiliki tanggung jawab terhadap tugasnya, serta sangat loyal terhadap perusahaan (Annisa \& Zulkarnain, 2013).

Dengan adanya komitmen dalam diri individu, maka semakin tinggi kepeduliannya terhadap organisasi, sehingga individu tersebut akan terus berusaha untuk menjadikan organisasinya ke arah yang lebih baik (Abdullah \& Arisanti, 2010). Komitmen karyawan yang tinggi akan membuat lebih stabil dan produktif dalam bekerja, sehingga akan membawa keuntungan bagi organisasi. Sebaliknya komitmen yang rendah akan menyebabkan kesulitan pada organisasi, karyawan tidak akan memberikan yang terbaik kepada organisasi dan dapat dengan mudah keluar dari organisasi (Teresia \& Suyasa, 2008).

Allen \& Meyer (1990) mengemukakan tiga komponen model komitmen terhadap organisasi, yaitu komitmen afektif menunjukkan kuatnya keinginan seseorang untuk terus bekerja bagi suatu organisasi atau perusahaan, komitmen berkelanjutan komitmen yang didasarkan pada pertimbangan tentang apa yang harus dikorbankan bila akan meninggalkan organisasi, komitmen normatif komitmen yang didasarkan pada kewajiban untuk tetap berada di dalam organisasi karena adanya tanggung jawab dari seorang karyawan.

\subsection{Organizational Citizenship Behavior}

Organizational Citizenship Behavior (OCB), atau bisa disebut juga dengan perilaku kewargaan organisasi, adalah istilah yang mencakup setiap hal positif dan konstruktif yang dilakukan oleh karyawan atas kemauan sendiri sehingga memberi manfaat pada sesama karyawan maupun pada perusahaan (Zhang, 2011). OCB adalah perilaku sukarela, melebihi beban tugasnya, tidak diwajibkan, dan tanpa penghargaan/imbalan, namun dapat berkontribusi konstruktif untuk kesuksesan organisasi. (Sweeney \& McFarlin, 2002; Newstrom \& Davis, 2002; DuBrin, 2000; dalam Teresia \& Suyasa, 2008). Skarlicki \& Latham (1996) menguatkan bahwa OCB mengacu pada kontribusi terhadap organisasi yang secara eksplisit tidak diwajibkan, serta tidak diberikan penghargaan oleh organisasi, walaupun berkontribusi terhadap efektivitas fungsi organisasi.

Terdapat lima dimensi dari OCB (Bateman \& Organ, 1983) yaitu altruism merupakan individu yang senang membantu, courtesy merupakan sikap ramah dan sopan untuk menghindari konflik, conscientiousness merupakan perhatian terhadap sekitar untuk mengurangi kesalahan, civic virtue merupakan minat dan keterlibatan, sportsmanship merupakan toleransi terhadap kondisi yang ideal, serta menerima perubahan dan melakukan permintaan tanpa mengeluh.

\subsection{Penelitian yang Relevan dan Pengembangan Hipotesis}

Penelitian Nurmatias (2015) menganalisis pengaruh etika kerja Islami, kepuasan kerja, dan komitmen organisasi terhadap kinerja karyawan. Penelitian yang melibatkan 60 responden yang merupakan karyawan Islamic Institute Tafaqquh Fiddin Dumai ini At-Tijaroh : Jurnal Ilmu Manajemen dan Bisnis Islam, Volume 5, Nomor 1 Tahun 2019 http://jurnal.iain-padangsidimpuan.ac.id/index.php/attijaroh 
mengajukan temuan dimana komitmen organisasi berpengaruh signifikan terhadap kinerja karyawan. Taurisa \& Ratnawati, (2012) juga telah melakukan kajian mengenai pengaruh budaya organisasi, kepuasan kerja, dan komitmen organisasional terhadap kinerja karyawan. Dengan objek penelitian yang merupakan 127 karyawan pada P.T. Sido Muncul Kaligawe Semarang, penelitian ini memberi kesimpulan bahwa: komitmen organisasional berpengaruh positif dan signifikan terhadap kinerja karyawan.

Sjahruddin, Armanu, Sudiro, \& Normijati (2013) telah mengeksplorasi hubungan antara keadilan organisasi dan OCB yang dimediasi oleh kepercayaan pada manajer dan komitmen organisasional. Dari data survei yang dikumpulkan dari 134 perawat di Rumah Sakit Kota Makassar Indonesia, hasil analisis dengan menggunakan SEM berbasis varians dengan analisis Partial Least Square (PLS) menunjukkan bahwa komitmen organisasional memiliki pengaruh yang signifikan terhadap OCB. Sedangkan Supriyanto (2013) yang meneliti tentang dampak keadilan prosedural, komitmen organisasional, dan kepuasan kerja terhadap kinerja karyawan, serta peran mediasi potensial yang ditimbulkan oleh OCB, dengan menggunakan sampel sebanyak 70 karyawan dari 15 cabang bank syariah besar di Malang, menunjukkan bahwa komitmen organisasional berpengaruh positif pada OCB. Komitmen organisasi berpengaruh positif terhadap kinerja karyawan, dan juga OCB secara positif mempengaruhi kinerja karyawan. Sedangkan menurut penelitian yang dilakukan oleh Nadim, Hassan, Abbas, \& Naveed (2016) yang menganalisis dampak komitmen organisasional dan persepsi dukungan organisasi dalam mempromosikan OCB 140 pengajar di universitas swasta dari Pakistan telah menunjukkan hasil dimana OCB adalah faktor yang cukup tergantung pada komitmen organisasional.

Adapun mengenai pengaruh OCB terhadap komitmen organisasional, Nursyamsi (2013) telah melakukan kajian yang bertujuan untuk mempelajari pengaruh perilaku dan OCB terhadap komitmen organisasional, serta pengaruhnya terhadap kinerja karyawan. Data primer dalam penelitian ini diambil dengan menggunakan kuesioner yang diberikan kepada 128 karyawan. Hasil penelitian ini menunjukkan bahwa OCB dan pemberdayaan karyawan berpengaruh signifikan terhadap komitmen organisasional. Sekaligus tingkat kinerja karyawan juga dipengaruhi secara positif oleh OCB. Darto (2014) juga telah melakukan kajian yang bertujuan untuk menganalisis peran OCB dalam peningkatan kinerja individu di sektor publik, dilihat dari perspektif teoritis dan empiris. Kajian ini menemukan bahwa OCB memiliki peran vital dalam meningkatkan kinerja karyawan secara individual di sektor publik, dimana OCB terbukti berhubungan secara signifikan terhadap kinerja individu. Senada dengan hasil penelitian tersebut, Harwiki (2016) yang mengkaji pengaruh servant leadership pada budaya organisasi, komitmen organisasional, dan $\mathrm{OCB}$, pengaruh budaya organisasi pada OCB dan kinerja karyawan, komitmen organisasi pada OCB dan kinerja 


\section{1 | Analisis Simultan Komitmen Organisasional dan Organizational Citizenship Behavior Terhadap Kinerja Karyawan}

karyawan, serta pengaruh OCB pada kinerja karyawan, yang dilakukan pada koperasi wanita di Jawa Timur, juga menemukan bahwa OCB memiliki pengaruh signifikan pada kinerja karyawan.

Dari beberapa hasil penelitian terdahulu diatas, dapat dirumuskan beberapa hipotesis berikut ini:

$\mathrm{H}_{1}$ : Komitmen organisasional memiliki pengaruh positif signifikan terhadap OCB

$\mathrm{H}_{2}$ : OCB memiliki pengaruh positif signifikan terhadap komitmen organisasional

$\mathrm{H}_{3}$ : Komitmen organisasional memiliki pengaruh positif signifikan terhadapkinerja karyawan

$\mathrm{H}_{4}$ : OCB memiliki pengaruh positif signifikan terhadapkinerja karyawan

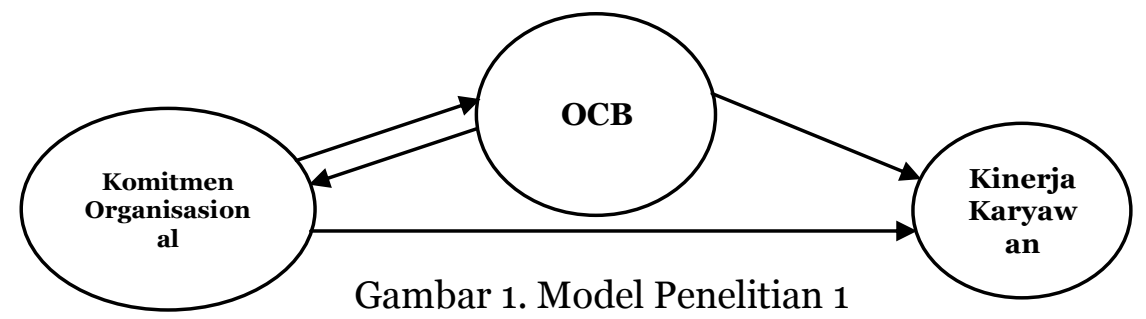

\section{METODE PENELITIAN}

\subsection{Populasi dan Sampel}

Dalam penelitian ini, populasi yang digunakan oleh peneliti adalah karyawan perusahaan P.T. XYZ (yang bergerak di bidang konveksi/garment), yang terletak di Kabupaten Wonogiri (Jawa Tengah), yang bekerja di Factory 1 (sejumlah 2.309 orang) dan Factory 2 (sejumlah 1.741 orang), sehingga totalnya adalah 4.050 orang. Populasi tersebut dipilih guna mengamati dan membuktikan beberapa hipotesis yang telah dipaparkan diatas.

Jumlah sampel adalah jumlah elemen yang dimasukkan ke dalam sampel (Ferdinand, 2014) Teknik pengambilan sampel pada penelitian ini menggunakan kriteria jumlah variabel independen yang dikalikan dengan angka 25, sebagaimana dinyatakan oleh Ferdinand (2014), sehingga jumlah minimal sampel yang diambil adalah 100 responden. Namun, untuk memperoleh hasil yang maksimal, khususnya untuk memperoleh data yang berdistribusi normal, maka ditetapkan sampel yang diambil adalah sebanyak 300 responden.

\subsection{Teknik Pengambilan Sampel}

Teknik pengambilan data yang digunakan adalah teknik probability sampling, dimana setiap anggota populasi mempunyai kesempatan yang sama untuk menjadi anggota sampel penelitian, dimana peneliti memilih menggunakan metode simple random sampling. Teknik pengambilan data ini merupakan teknik yang sederhana, karena kuesioner dapat disebar kepada semua populasi yang ada untuk memberikan jawaban atas item pernyataan yang ada di dalam kuesioner (Kuncoro, 2009).

At-Tijaroh : Jurnal Ilmu Manajemen dan Bisnis Islam, Volume 5, Nomor 1 Tahun 2019 http://jurnal.iain-padangsidimpuan.ac.id/index.php/attijaroh 


\subsection{Teknik Pengumpulan Data}

Data dari sampel diambil melalui survei kuesioner, dengan memberikan beberapa daftar pernyataan yang diisi oleh setiap responden. Responden diminta pendapatnya dengan memberikan jawaban dari pernyataan yang mewakili setiap indikator dari masing-masing variabel yang diajukan melalui kuesioner tersebut.

\subsection{Teknik Analisis Data}

\subsubsection{Uji Validitas dan Reliabilitas}

Sebelum penelitian dilakukan, perlu dilakukan pengujian terhadap validitas dan reliabilitas terhadap daftar pertanyaan yang digunakan. Pengujian validitas dan reliabilitas daftar pertanyaan ini dimaksudkan agar daftar pertanyaan yang digunakan untuk mendapatkan data penelitian memiliki tingkat validitas dan reliabilitas yang memenuhi batasan yang disyaratkan.

\subsubsection{Analisis Data}

Penelitian ini menggunakan metode analisis Structural Equation Modelling (SEM) yang dioperasikan melalui program IBM AMOS Graphics 21. SEM merupakan kombinasi dari analisis faktor dan analisis regresi, diman adengan teknik ini, peneliti mampu menguji beberapa variabel dependen sekaligus, dengan beberapa variabel independen yang memiliki rangkaian hubungan yang rumit dengan pengujian statistik secara simultan (Ferdinand, 2002). Dua teknik analisis digunakan secara bertahap dalam penelitian ini, yaitu model pengukuran (measurement model) yang mana model ini ditujukan untuk mengkonfirmasi dimensi yang dikembangkan pada variabel yang diteliti. Variabel-variabel penelitian akan diuji unidimensionalitasnya dalam membentuk variabel laten (Ferdinand, 2002). Unidimensionalitas adalah kemampuan indikator untuk dapat mengukur satu konstruk (Hair, Black, Babin, \& Anderson, 2010) dan model struktural (structural model) yang mana model ini merupakan model struktur hubungan yang membentuk atau menjelaskan kausalitas antar variabel yang diteliti. Dalam model ini juga akan diukur hubungan sebab akibat antara berbagai konsep variabel yang akan diukur. Pengujian hipotesis dilakukan melalui goodness of fit dari model penelitian dan hubungan dalam model yang disampaikan (Hair et al., 2010). Sebuah pemodelan SEM mensyaratkan adanya ukuran sampel, normalitas data, tidak hanya outlier, serta tidak adanya masalah dalam multicollinearity dan singularity (Ferdinand, 2002). Terdapat tujuh langkah yang harus dilakukan apabila menggunakan SEM, yaitu pengembangan model teoritis, pengembangan diagram alur (path diagram), memilih matriks input dan estimasi model, kemungkinan munculnya masalah identifikasi, evaluasi kriteria goodness of fit, interpretasi, dan modifkasi (Hair et al., 2010). 


\section{3 | Analisis Simultan Komitmen Organisasional dan Organizational}

Citizenship Behavior Terhadap Kinerja Karyawan

\section{HASIL DAN PEMBAHASAN}

\subsection{Deskripsi Data}

Responden dalam penelitian ini adalah karyawan tetap pada P.T. XYZ, dari berbagai bagian kerja. Jumlah responden adalah sebanyak 300 orang, namun setelah melalui penyaringan data dan menghilangkan outlier pada data, pada penelitian ini diambil sampel sebanyak 258 responden.

\subsection{Analisis Data}

\subsubsection{Validitas}

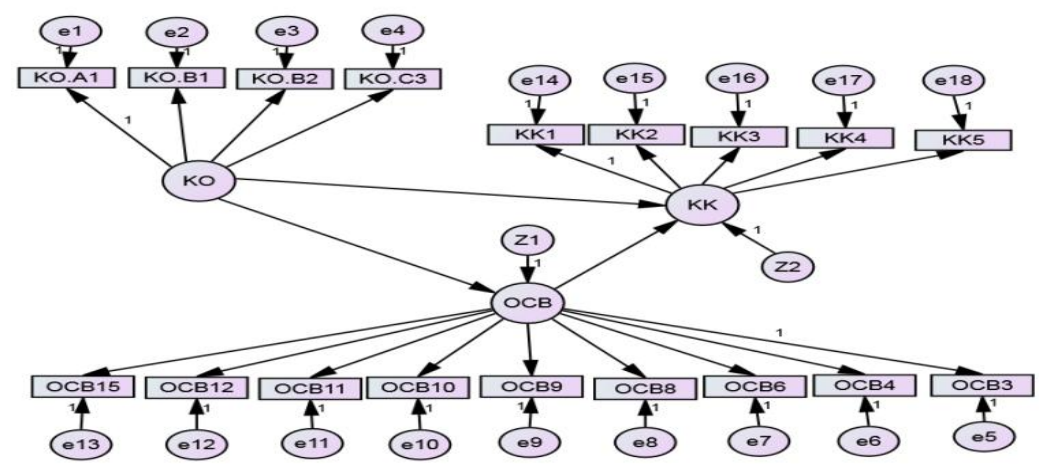

Gambar 2. Model Penelitian 1

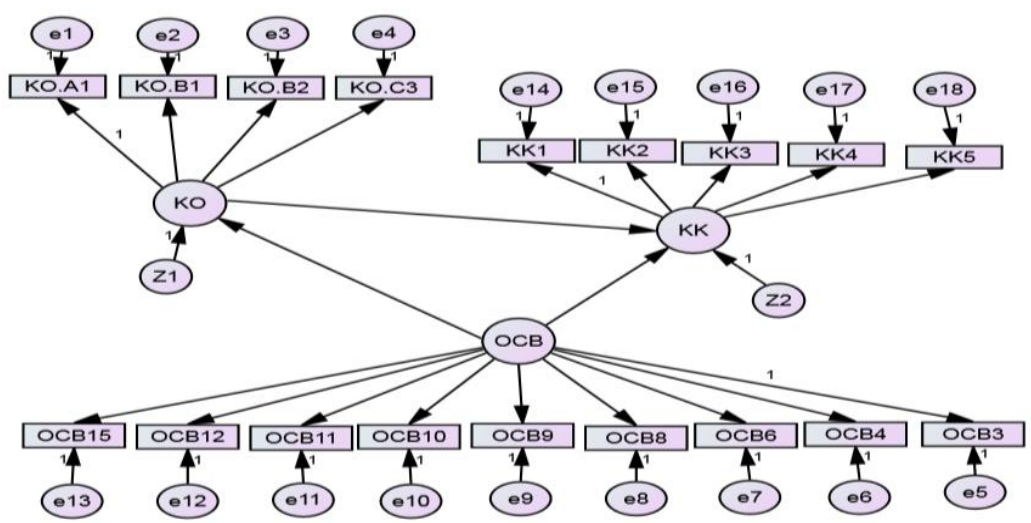

Gambar 3. Model Penelitian 2

Tabel 1

Convergent Validity

\begin{tabular}{llrlrrr}
\hline & & & \multicolumn{2}{c}{ Model 1 } & \multicolumn{2}{c}{ Model 2 } \\
\cline { 3 - 6 } & & & Bobot Faktor & Ket & Bobot Faktor & Ket \\
\hline KO1 & $<---$ & KO &, 751 & Valid &, 751 & Valid \\
KO5 & $<---$ & KO &, 752 & Valid &, 752 & Valid \\
KO6 & $<---$ & KO &, 772 & Valid &, 772 & Valid \\
KO12 & $<---$ & KO &, 695 & Valid &, 695 & Valid \\
KK1 & $<---$ & KK &, 737 & Valid &, 737 & Valid \\
KK2 & $<---$ & KK &, 816 & Valid &, 816 & Valid \\
KK3 & $<---$ & KK &, 700 & Valid &, 700 & Valid
\end{tabular}

At-Tijaroh : Jurnal Ilmu Manajemen dan Bisnis Islam, Volume 5, Nomor 1 Tahun 2019 http://jurnal.iain-padangsidimpuan.ac.id/index.php/attijaroh 


\begin{tabular}{llllcrc} 
KK4 & $<---$ & KK &, 505 & Valid &, 505 & Valid \\
KK5 & $<---$ & KK &, 071 & Tidak Valid &, 071 & Tidak Valid \\
OCB3 & $<---$ & OCB &, 699 & Valid &, 699 & Valid \\
OCB4 & $<---$ & OCB &, 569 & Valid &, 569 & Valid \\
OCB6 & $<---$ & OCB &, 709 & Valid &, 709 & Valid \\
OCB8 & $<---$ & OCB &, 683 & Valid &, 683 & Valid \\
OCB9 & $<---$ & OCB &, 182 & Tidak Valid &, 182 & Tidak Valid \\
OCB10 & $<---$ & OCB &, 756 & Valid &, 756 & Valid \\
OCB11 & $<---$ & OCB &, 792 & Valid &, 792 & Valid \\
OCB12 & $<---$ & OCB &, 591 & Valid &, 591 & Valid \\
OCB15 & $<---$ & OCB &, 411 & Valid &, 411 & Valid \\
\hline \multicolumn{6}{c}{ Sumber: }
\end{tabular}

Sumber: Data yang Diolah (2019)

Dari tabel diatas, dapat diketahui bahwa instrumen yang digunakan untuk mengukur indikator dinyatakan valid, kecuali pada item KK5 dan OCB 9. Dua instrumen tersebut dinyatakan tidak valid dikarenakan memiliki bobot faktor 0,114 dan 0,192, sedangkan instrumen lainnya mendekati atau lebih dari 0,5 sehingga dinyatakan valid sesuai dengan batasan nilai convergent validity (Ghozali, 2011). Oleh karena itu, maka selanjutnya akan dilakukan pengujian ulang dengan menghilangkan instrumen KK5 dan OCB 9.

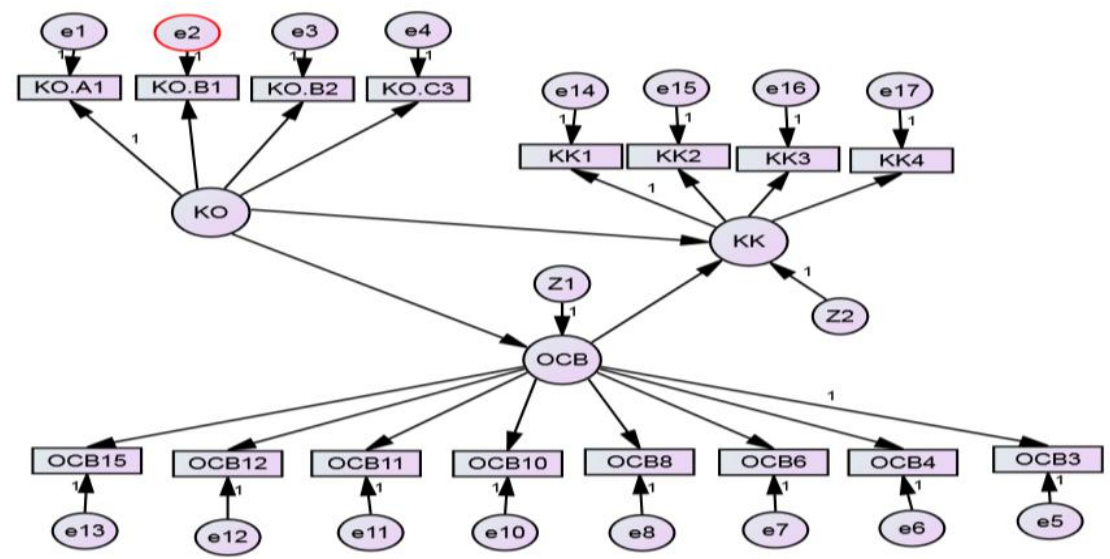

Gambar 4. Model Penelitian 1 (Setelah Instrumen KK5 dan OCB9 Dihapus)

Tabel 2

Convergent Validity (Setelah Instrumen $\mathrm{KK}_{5}$ dan OCB9 Dihapus)

\begin{tabular}{lllllcc}
\hline & & & \multicolumn{2}{c}{ Model 1 } & \multicolumn{2}{c}{ Model 2 } \\
\cline { 3 - 7 } & & & $\begin{array}{c}\text { Bobot } \\
\text { Faktor }\end{array}$ & Keterangan & $\begin{array}{c}\text { Bobot } \\
\text { Faktor }\end{array}$ & Keterangan \\
\hline KO1 & $<---$ & KO &, 751 & Valid &, 751 & Valid \\
KO5 & $<---$ & KO &, 752 & Valid &, 752 & Valid \\
KO6 & $<---$ & KO &, 772 & Valid &, 772 & Valid \\
KO12 & $<---$ & KO &, 695 & Valid &, 695 & Valid \\
KK1 & $<---$ & KK &, 735 & Valid &, 735 & Valid \\
KK2 & $<---$ & KK &, 817 & Valid &, 817 & Valid \\
KK3 & $<---$ & KK &, 701 & Valid &, 701 & Valid \\
KK4 & $<---$ & KK &, 505 & Valid &, 505 & Valid \\
OCB3 & $<---$ & OCB &, 701 & Valid &, 071 & Valid
\end{tabular}

At-Tijaroh : Jurnal Ilmu Manajemen dan Bisnis Islam, Volume 5, Nomor 1 Tahun 2019

http://jurnal.iain-padangsidimpuan.ac.id/index.php/attijaroh 
125 | Analisis Simultan Komitmen Organisasional dan Organizational Citizenship Behavior Terhadap Kinerja Karyawan

\begin{tabular}{lllllll} 
OCB4 & $<---$ & OCB &, 572 & Valid &, 572 & Valid \\
OCB6 & $<---$ & OCB &, 712 & Valid &, 712 & Valid \\
OCB8 & $<---$ & OCB &, 681 & Valid &, 681 & Valid \\
OCB10 & $<---$ & OCB &, 753 & Valid &, 753 & Valid \\
OCB11 & $<---$ & OCB &, 791 & Valid &, 791 & Valid \\
OCB12 & $<---$ & OCB &, 590 & Valid &, 590 & Valid \\
OCB15 & $<---$ & OCB &, 411 & Valid &, 411 & Valid \\
\hline
\end{tabular}

Sumber: Data yang Diolah (2019)

Dari tabel diatas, dapat diketahui bahwa instrumen yang digunakan untuk mengukur indikator dinyatakan valid. Sesuai dengan batasan nilai convergent validity (Ghozali, 2011), yaitu semua instrumen memiliki bobot faktor di atas atau mendekati o,5.

\subsubsection{Reliabilitas}

\subsubsection{Komitmen Organisasional}

Tabel 3

Hasil Uji Reliabilitas Konstruk Komitmen Organisasional

\begin{tabular}{lrcl}
\hline \multicolumn{1}{c}{ Item } & Std. loading & (Std. Loading) $^{2}$ & $\varepsilon j$ \\
\hline KO1 &, 751 &, 564 & 0,436 \\
KO5 &, 752 &, 566 & 0,434 \\
KO6 &, 772 &, 596 & 0,404 \\
KO 12 &, 695 &, 483 & 0,517 \\
$\mathbf{\Sigma}$ & 2,97 & 2,208 & 1,79 \\
\hline
\end{tabular}

Sumber: Data yang Diolah (2019)

Variance extracted $=\frac{(2,97)^{2}}{(2,97)^{2}+1,79}=0,83$

Perhitungan variance extracted untuk variabel komitmen organisasional menghasilkan nilai 0,83 . Hal ini menunjukan bahwa nilai tersebut sudah memenuhi batasan yang dapat diterima, yaitu o,5. Dengan demikian, maka konstruk komitmen organisasional memiliki reliabilitas yang baik. Sehingga item-item yang ada sudah handal untuk mengukur variabel komitmen organisasional.

\subsubsection{OCB}

Tabel 4

Hasil Uji Reliabilitas OCB

\begin{tabular}{ccrr}
\hline Item & Std. Loading & (Std. Loading) $^{2}$ & \multicolumn{1}{l}{ घj } \\
\hline OCB3 &, 701 &, 491 &, 509 \\
OCB4 &, 572 &, 327 &, 673 \\
OCB6 &, 712 &, 507 &, 493 \\
OCB8 &, 681 &, 464 &, 536 \\
OCB10 &, 753 &, 567 &, 433 \\
OCB11 &, 791 &, 626 &, 374 \\
OCB12 &, 590 &, 348 &, 652 \\
OCB15 &, 411 &, 169 &, 831 \\
$\mathbf{\Sigma}$ & 5,21 & 3,5 & 4,50 \\
\hline
\end{tabular}

Sumber: Data yang Diolah (2019) 


$$
\text { Variance extracted }=\frac{(5,21)^{2}}{(5,21)^{2}+4,5}=0,86
$$

Perhitungan variance extracted untuk variabel OCB menghasilkan nilai o,86. Hal ini menunjukan bahwa nilai tersebut sudah memenuhi batasan yang dapat diterima, yaitu 0,5. Dengan demikian, maka konstruk OCB memiliki reliabilitas yang baik. Sehingga item-item yang ada sudah handal untuk mengukur variabel OCB.

\subsubsection{Kinerja Karyawan}

Tabel 4.5.

Hasil Uji Reliabilitas Kinerja Karyawan

\begin{tabular}{crrr}
\hline Item & Std. loading & (Std. Loading) $^{2}$ & \multicolumn{1}{c}{$\varepsilon j$} \\
\hline KK1 &, 735 &, 540 &, 460 \\
KK2 &, 817 &, 667 &, 333 \\
KK3 &, 701 &, 491 &, 509 \\
KK4 &, 505 &, 255 &, 745 \\
$\mathbf{\Sigma}$ & 2,758 & 1,954 & 2,046 \\
\hline
\end{tabular}

Sumber: Data yang Diolah (2019)

$$
\text { Variance extracted }=\frac{(2,758)^{2}}{(2,758)^{2}+2,046}=0,79
$$

Perhitungan variance extracted untuk variabel kinerja karyawan menghasilkan nilai 0,79. Hal ini menunjukan bahwa nilai tersebut sudah memenuhi batasan yang dapat diterima, yaitu 0,5. Dengan demikian, maka konstruk kinerja karyawan memiliki reliabilitas yang baik. Sehingga item-item yang ada sudah handal untuk mengukur variabel OCB.

\subsubsection{Uji Goodness of Fit}

Hasil output SEM terkait goodness of fit model penelitian ini digambarkan pada gambar 4.2. dan tabel 4.2. sebagai berikut:

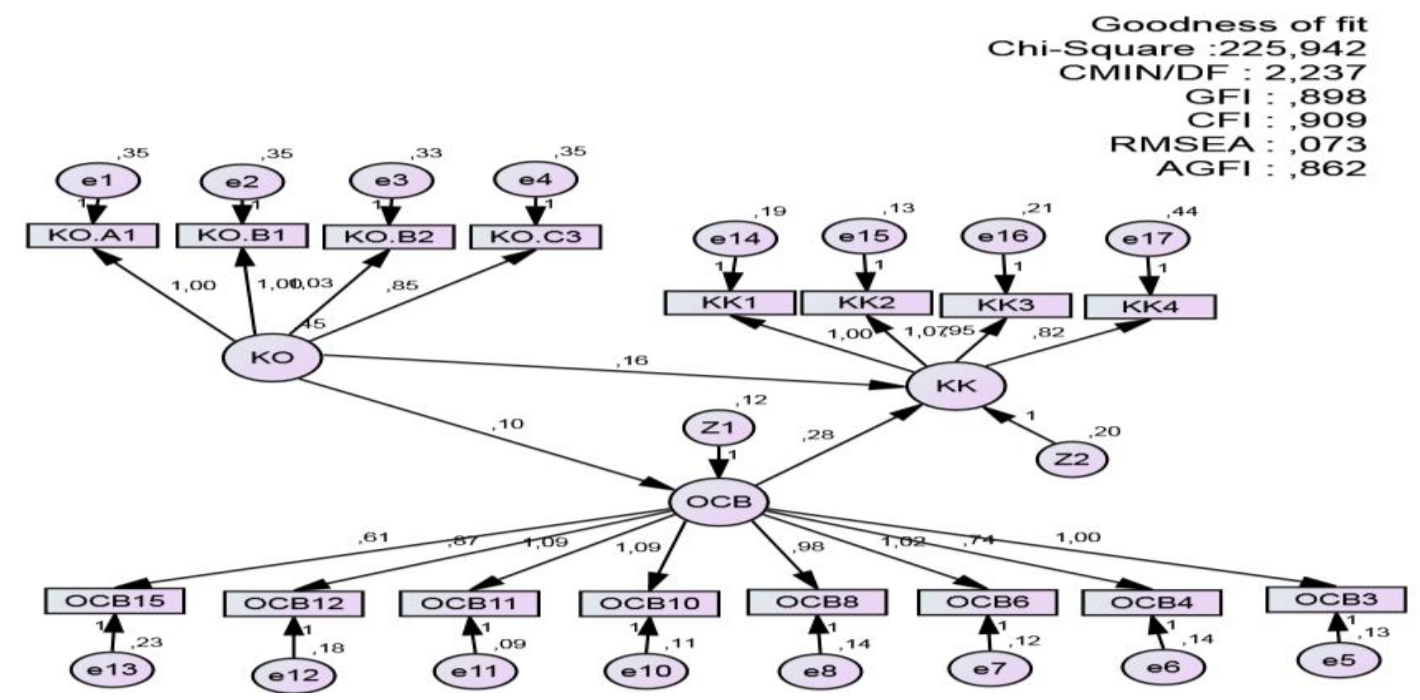

Gambar 5. Model 1 


\section{7 | Analisis Simultan Komitmen Organisasional dan Organizational Citizenship Behavior Terhadap Kinerja Karyawan}

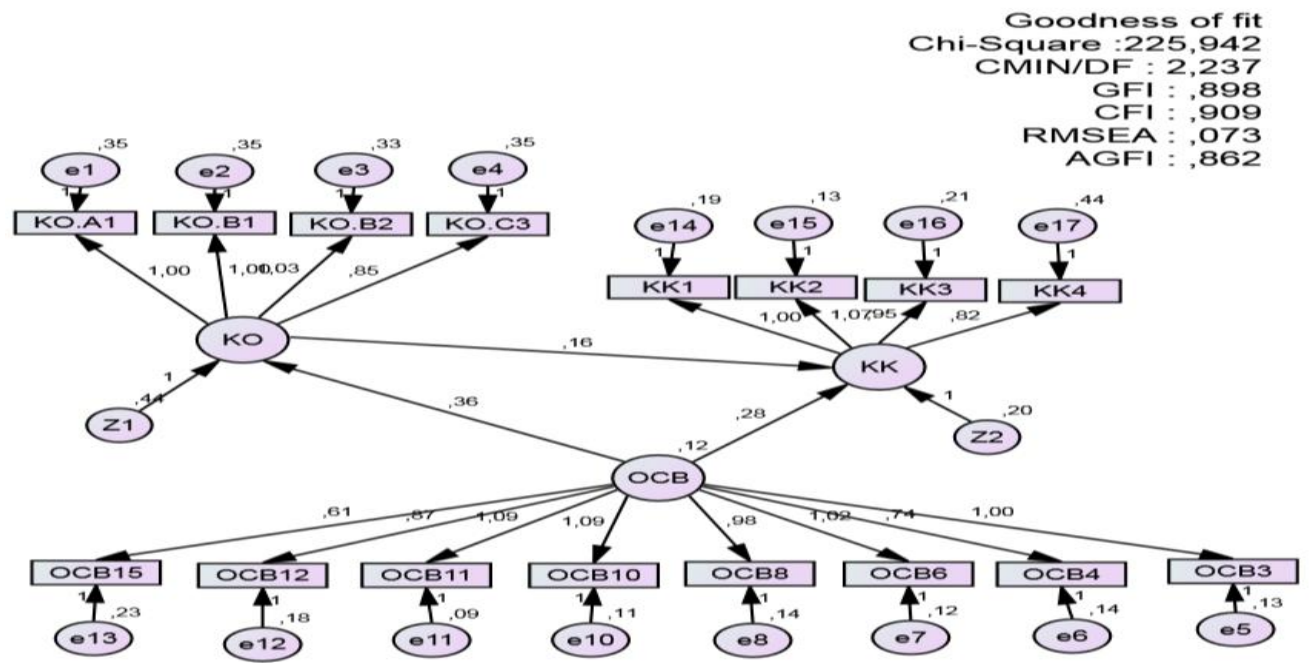

Gambar 6. Model 2

Tabel 6

Evaluasi Goodness of Fit

\begin{tabular}{cccc}
\hline $\begin{array}{c}\text { Indeks Model } \\
\text { Goodness of Fit }\end{array}$ & Cut off Value & $\begin{array}{c}\text { Hasil } \\
\text { Model }\end{array}$ & Kesimpulan \\
\hline Chi Square & Diharapkan kecil & 225,942 & Fit \\
CMIN/DF & $\leq 2,00$ & 2,237 & Marginal \\
CFI & $\geq 0,95$ & 0,909 & Marginal \\
RMSEA & $\leq 0,08$ & 0,073 & Fit \\
GFI & $\geq 0,90$ & 0,898 & Fit \\
TLI & $\geq 0,90$ & 0,892 & Fit \\
AGFI & $\geq 0,90$ & 0,862 & Marginal \\
\hline
\end{tabular}

Sumber: Data yang Diolah (2019)

Berdasarkan hasil pengukuran masing-masing kriteria goodness of fit yang dapat dilihat dari gambar dan tabel diatas, dapat diketahui bahwa nilai chi-square sebesar 225,942, dan nilai chi-square ini diharapkan kecil. Maka hal ini menunjukan bahwa model pengukuran yang digunakan hasilnya baik atau dapat diterima. CMIN/DF merupakan nilai chi-square dibagi dengan degree of freedom. Nilai CMIN/DF pada penelitian ini adalah 2,237 dengan syarat pengujian $\leq 2$. Dengan demikian maka nilai CMIN/DF dalam penelitian ini memiliki nilai marginal, sehingga model penelitian ini cukup fit. Comparative Fit Index (CFI) mempunyai rentang nilai sebesar o - 1, dimana jika semakin mendekati 1 maka mengindikasikan tingkat fit yang paling tinggi. Nilai yang direkomendasikan adalah CFI $\geq$ 0,95. Dari hasil pengujian diatas menghasilkan nilai 0,909, sehingga nilai CFI dalam penelitian ini memiliki nilai marginal, sehingga model cukup fit. The Root Mean Square Error of Approximation (RMSEA) adalah sebuah indeks yang dapat digunakan untuk mengkompensasi chi-square statistik dalam sampel yang besar. Dalam tabel diatas diketahui bahwa nilai pengukuran RMSEA adalah 0,073. Dengan nilai RMSEA yang direkomendasikan adalah $\leq 0,08$, maka dengan demikian menunjukan bahwa model dapat diterima.Goodness of Fit Index (GFI) merupakan indeks kesesuaian (fit index) yang akan menghitung proporsi tertimbang dari varians dalam matriks kovarian sampel yang dijelaskan oleh matriks At-Tijaroh : Jurnal Ilmu Manajemen dan Bisnis Islam, Volume 5, Nomor 1 Tahun 2019 http://jurnal.iain-padangsidimpuan.ac.id/index.php/attijaroh 
kovarian populasi yang terestimastikan. Hasil pengukuran untuk GFI dalam penelitian ini sebesar 0,898. Maka dengan demikian menunjukan bahwa model dapat diterima. Tucker Lewis Index (TLI) merupakan alternatif fit index yang membandingkan sebuah model yang diuji terhadap sebuah baseline model. Nilai yang direkomendasikan sebagai acuan untuk diterimanya sebuah model adalah $\geq 0,90$. Diketahui bahwa hasil pengukuran TLI sebesar o,892, sehingga menunjukan bahwa model dapat diterima. Adjusted Goodness of Fit Index (AGFI) mempunyai tingkat penerimaan yang direkomendasikan sebesar $\geq 0,90$. Hasil pegukuran dari penelitian ini sebesar 0,862 . Hal ini berati model dikatakan memiliki kesesuaian model yang baik.

Berdasarkan penjelasan diatas, dapat disimpulkan bahwa nilai chi-square, CMIN/DF, TLI, GFI, CFI, RMSEA, dan AGFI telah memenuhi cut off value dalam batas marginal, maka dapat disimpulkan bahwa model tersebut dikatakan fit, sehingga dapat dilakukan tahapan pengujian selanjutnya.

\subsubsection{Uji Asumsi SEM}

\subsubsection{Uji Pengukuran Sampel}

Sampel yang digunakan dalam penelitian ini berjumlah 258 responden. Jumlah sampel ini telah memenuhi asumsi SEM yang mengharuskan jumlah sampel diantara 100-200 responden (Ferdinand, 2014). Jika jumlah sampel yang didapat kurang dari atau tidak memenuhi asumsi SEM, maka akan sulit mendapatkan nilai goodness of fit yang sesuai.

\subsubsection{Uji Normalitas}

Pada penelitian ini, normalitas dapat dilihat dari tabel berikut:

Tabel 7

Tabel Normalitas Model 1 dan Model 2

\begin{tabular}{lccrrrr}
\hline \multicolumn{1}{c}{ Variable } & min & max & Skew & \multicolumn{1}{c}{ c.r. } & kurtosis & \multicolumn{1}{c}{ c.r. } \\
\hline OCB15 & 3,000 & 5,000 &, 201 & 1,255 &,- 337 & $-1,053$ \\
OCB12 & 3,000 & 5,000 &, 231 & 1,441 &,- 514 & $-1,604$ \\
OCB11 & 2,000 & 5,000 &, 272 & 1,697 & 1,338 & 4,179 \\
OCB10 & 3,000 & 5,000 &, 176 & 1,096 &, 635 & 1,983 \\
OCB8 & 3,000 & 5,000 &, 335 & 2,091 &,- 619 & $-1,933$ \\
OCB6 & 3,000 & 5,000 &, 358 & 2,237 &,- 941 & $-2,937$ \\
OCB4 & 2,000 & 5,000 &,- 005 &,- 031 & 4,128 & 12,890 \\
OCB3 & 3,000 & 5,000 &, 375 & 2,344 &,- 916 & $-2,861$ \\
KK4 & 1,000 & 5,000 &, 233 & 1,455 & 1,272 & 3,973 \\
KK3 & 1,000 & 5,000 &, 252 & 1,576 & 3,155 & 9,852 \\
KK2 & 1,000 & 5,000 &, 364 & 2,275 & 2,913 & 9,095 \\
KK1 & 1,000 & 5,000 &, 163 & 1,015 & 3,452 & 10,778 \\
KO12 & 2,000 & 5,000 &,- 393 & $-2,455$ &,- 519 & $-1,620$ \\
KO6 & 2,000 & 5,000 &,- 413 & $-2,576$ &,- 650 & $-2,030$ \\
KO5 & 2,000 & 5,000 &,- 316 & $-1,972$ &,- 716 & $-2,236$ \\
KO1 & 2,000 & 5,000 &,- 114 &,- 714 &,- 759 & $-2,370$ \\
Multivariate & & & & & 46,399 & 14,787 \\
\hline
\end{tabular}

Sumber: Data yang Diolah (2019) 


\section{9 | Analisis Simultan Komitmen Organisasional dan Organizational Citizenship Behavior Terhadap Kinerja Karyawan}

Pada tabel diatas dapat dietahui bahwa data telah berdistribusi normal secara univariate. Hal ini dapat dilihat dari nilai critical value yang berada di bawah $\pm 2,58$. Namun hasil uji normalitas tersebut tidak normal secara multivariate karena memiliki nilai normalitas lebih dari $\pm 2,58$ sehingga diperlukan dilakukan estimasi dengan prosesur bootstrap. Metode bootstrap digunakan untuk mengatasi pelanggaran asumsi normalitas secara multivariate. Metode ini berbasis resampling, dimana pada pengujian ini peneliti melakukan resampling sebanyak 2000 kali, dengan langkah sebagai berikut:

1. The Bolen-Stine Bootstrap

Tabel 8

Hasil The Bolen-Stine Bootstrap

\begin{tabular}{cc}
\hline failed to fit & 1 bootstrap samples \\
\hline Bollen-Stine bootstrap $p$ & 0,001
\end{tabular}

Sumber: Data yang Diolah (2019)

Hasil ini menunjukan bahwa probabilitas Bollen-Stine bootstrap bernilai 0,o01. Probabilitas Bollen-Stine $\leq$ 0,05, sehingga diperlukan uji bootstrap pada parameter.

2. Bootstrap pada Paramater

Tabel 9

Bootstrap pada Paramater

\begin{tabular}{lrlrrr}
\hline & Parameter & Estimate & SE ML & \multicolumn{2}{c}{ SE Bootstrap } \\
\hline KO & $<---$ & OCB & 0,363 & 0,150 & 0,152 \\
OCB & $<---$ & KO & 0,098 & 0,040 & 0,042 \\
KK & $<---$ & KO & 0,162 & 0,057 & 0,070 \\
KK & $<---$ & OCB & 0,281 & 0,106 & 0,115 \\
\hline
\end{tabular}

Sumber: Data yang Diolah (2019)

Hasil dari nilai standarized error diatas dibandingkan antara data original sample dengan bootstrap sample. Variabel OCB ke komitmen organisasional memiliki perbedaan sebesar $(0,152-0,150)=0,002$, yang berarti terdapat penurunan $0,2 \%$ standard error dari bootstrap dibandingkan dengan standard error dari original sample. Variabel komitmen organisasional ke OCB memiliki perbedaan sebesar $(0,042-0,040)=0,002$, yang berarti terdapat penurunan $0,2 \%$ standard error dari bootstrap dibandingkan dengan standard error dari original sample. Variabel komitmen organisasional ke kinerja karyawan memiliki perbedaan sebesar $(0,070-0,057)=0,013$, yang berarti terdapat penurunan 1,3 \% standard error dari bootstrap dibandingkan dengan standard error dari original sample. Kemudian yang terakhir, OCB ke kinerja karyawan memiliki perbedaan sebesar $(0,115-0,106)=0,007$, yang berarti terdapat penurunan $0,7 \%$ standard error dari bootstrap dibandingkan dengan standard error dari original sample.

Tabel 10

Bias Coreccted Confidence Interval

\begin{tabular}{lrlrrr}
\hline \multicolumn{3}{c}{ Parameter } & Estimate & Lower & \multicolumn{1}{c}{ Upper } \\
\hline KO & $<---$ & OCB & 0,363 & 0,21 & 0,621 \\
OCB & $<---$ & KO &, 098 &, 026 &, 165
\end{tabular}

At-Tijaroh : Jurnal Ilmu Manajemen dan Bisnis Islam, Volume 5, Nomor 1 Tahun 2019 http://jurnal.iain-padangsidimpuan.ac.id/index.php/attijaroh 


\begin{tabular}{lrlrrr}
\hline \multicolumn{3}{c}{ Parameter } & Estimate & Lower & \multicolumn{1}{c}{ Upper } \\
\hline KK & $<---$ & KO &, 162 &, 060 &, 288 \\
KK & $<---$ & OCB &, 281 &, 102 &, 481 \\
KO1 & $<---$ & KO & 1,000 & 1,000 & 1,000 \\
\hline KO5 & $<---$ & KO & 1,004 &, 853 & 1,193 \\
KO6 & $<---$ & KO & 1,033 &, 891 & 1,206 \\
KO12 & $<---$ & KO &, 853 &, 721 & 1,006 \\
KK1 & $<---$ & KK & 1,000 & 1,000 & 1,000 \\
KK2 & $<---$ & KK & 1,072 &, 919 & 1,278 \\
KK3 & $<---$ & KK &, 954 &, 758 & 1,214 \\
KK4 & $<---$ & KK &, 823 &, 550 & 1,169 \\
OCB3 & $<---$ & OCB & 1,000 & 1,000 & 1,000 \\
OCB4 & $<---$ & OCB &, 741 &, 582 &, 897 \\
OCB6 & $<---$ & OCB & 1,018 &, 927 & 1,117 \\
OCB8 & $<---$ & OCB &, 980 &, 857 & 1,128 \\
OCB10 & $<---$ & OCB & 1,089 &, 945 & 1,271 \\
OCB11 & $<---$ & OCB & 1,087 &, 941 & 1,260 \\
OCB12 & $<---$ & OCB &, 873 &, 709 & 1,073 \\
OCB15 & $<---$ & OCB &, 612 &, 439 &, 790 \\
\hline Sumber: Data yang Diolah $(2019)$ & &
\end{tabular}

Informasi lain untuk menilai hasil bootstrap adalah bias corrected confidence interval. Dari tabel diatas, dapat diketahui bahwa semua loading factor pada masing-masing variabel memiliki range (antara lower dan upper) tidak termasuk nol, sehingga variabel dapat diterima. Dengan demikian, maka dapat dikatakan bahwa model dapat diterima.

\subsubsection{Evaluasi Outlier}

Terdapatnya outlier dalam data dapat diketahui melalui nilai statistik chi-square terhadap nilai Mahalanobis distance square dengan tingkat signifikansi o,oo dengan degree of freedom yaitu sejumlah konstruk yang digunakan dalam penelitian ini (Ghozali, 2011). Dasar teori tersebut digunakan dalam penelitian ini untuk mengetetahui jumlah outlier data yang harus dihilangkan untuk pengujian selanjutnya.

Hasil dari evaluasi outlier menjelaskan bahwa semua data memenuhi syarat, yaitu diatas signifikansi o,oo, sehingga penelitian ini dapat melakukan pengujian selanjutnya. Data outlier dapat dilihat melalui tabel Mahalanobis distance square pada berikut ini:

Tabel 11

Mahalanobis Distance Square

Observations farthest from the centroid (Mahalanobis distance) (Group number 1)

\begin{tabular}{rrrr}
\hline $\begin{array}{c}\text { Observation } \\
\text { number }\end{array}$ & $\begin{array}{c}\text { Mahalanobis } \\
\text { d-squared }\end{array}$ & $\mathrm{p} 1$ & $\mathrm{p} 2$ \\
\hline 185 & 42,440 & ,000 & ,076 \\
143 & 39,657 & ,001 & ,018 \\
23 & 38,408 & ,001 & ,004 \\
144 & 37,721 & ,002 & ,001 \\
210 & 37,010 & ,002 & ,000
\end{tabular}

At-Tijaroh : Jurnal Ilmu Manajemen dan Bisnis Islam, Volume 5, Nomor 1 Tahun 2019 http://jurnal.iain-padangsidimpuan.ac.id/index.php/attijaroh 


\begin{tabular}{|c|c|c|c|}
\hline $\begin{array}{l}\text { Observation } \\
\text { number }\end{array}$ & $\begin{array}{c}\text { Mahalanobis } \\
d \text {-squared }\end{array}$ & $\mathrm{p} 1$ & p2 \\
\hline 84 & 36,053 & ,003 & , OOO \\
\hline 149 & 34,802 & ,004 & , 000 \\
\hline 141 & 34,027 & ,005 & ,000 \\
\hline 209 & 33,784 & ,006 & , 000 \\
\hline 76 & 33,734 & ,006 & , 000 \\
\hline 25 & 33,123 & ,007 & , 000 \\
\hline 229 & 32,813 & ,008 & ,000 \\
\hline 16 & 32,647 & ,008 & , 000 \\
\hline 45 & 32,410 & ,009 & , 000 \\
\hline 29 & 32,305 & ,009 & ,000 \\
\hline 190 & 31,326 & ,012 & , 000 \\
\hline 55 & 31,199 & ,013 & , 000 \\
\hline 26 & 31,065 & ,013 & , OOO \\
\hline 48 & 30,878 & ,014 & , OOO \\
\hline 165 & 30,228 & ,017 & , 000 \\
\hline 17 & 30,224 & ,017 & , 000 \\
\hline 93 & 28,694 & ,026 & , 000 \\
\hline 205 & 28,485 & ,028 & ,000 \\
\hline 101 & 28,329 & ,029 & , 000 \\
\hline 135 & 27,770 & ,o34 & , 000 \\
\hline 33 & 27,717 & ,o34 & , OOO \\
\hline 69 & 27,587 & ,035 & , 000 \\
\hline 158 & 27,227 & ,039 & , 000 \\
\hline 96 & 27,172 & ,040 & , 000 \\
\hline 85 & 27,128 & ,040 & , o0O \\
\hline 153 & 26,802 & ,044 & ,000 \\
\hline 37 & 26,442 & ,048 & , 000 \\
\hline 10 & 26,371 & ,049 & , 000 \\
\hline 42 & 26,171 & ,052 & ,000 \\
\hline 97 & 25,589 & ,060 & , 000 \\
\hline 8 & 25,539 & ,061 & , OOO \\
\hline 224 & 25,025 & ,069 & , OOO \\
\hline 1 & 24,778 & , O74 & , OOO \\
\hline 192 & 24,181 & ,o86 & , 000 \\
\hline 103 & 23,968 & ,090 & , 000 \\
\hline 59 & 23,848 & ,093 & , 000 \\
\hline 136 & 23,843 & ,093 & , 000 \\
\hline 204 & 23,684 & ,097 & , 000 \\
\hline 132 & 23,632 & ,098 & , 000 \\
\hline 140 & 23,632 & ,098 & , 000 \\
\hline 58 & 23,302 & 106 & ,000 \\
\hline 231 & 22,696 & 122 & , OOO \\
\hline 170 & 22,473 & 129, & ,001 \\
\hline 171 & 22,473 & 129 & ,000 \\
\hline 152 & 22,286 & 134, & ,001 \\
\hline
\end{tabular}




\begin{tabular}{|c|c|c|c|}
\hline $\begin{array}{c}\text { Observation } \\
\text { number }\end{array}$ & $\begin{array}{c}\text { Mahalanobis } \\
\text { d-squared }\end{array}$ & $\mathrm{p} 1$ & p2 \\
\hline 67 & 22,142 & 139 & ,001 \\
\hline 146 & 22,068 & ,141 & ,001 \\
\hline 36 & 21,680 & 154 & ,002 \\
\hline 111 & 21,340 & 166 & ,006 \\
\hline 24 & 21,195 & 171 & ,008 \\
\hline 102 & 21,049 & 177 & ,009 \\
\hline 225 & 20,978 & 179 & ,008 \\
\hline 161 & 20,927 & 181 & ,007 \\
\hline 3 & 20,902 & 182 & ,005 \\
\hline 222 & 20,867 & 184 & ,004 \\
\hline 34 & 20,721 & 189 & ,005 \\
\hline 147 & 20,628 & 193 & ,005 \\
\hline 60 & 20,571 & 196 & ,004 \\
\hline 194 & 20,539 & 197, & ,003 \\
\hline 197 & 20,510 & ,198 & ,002 \\
\hline 53 & 20,456 & 200 & ,002 \\
\hline 51 & 20,298 & 207 & ,002 \\
\hline 62 & 20,191 & 212 & ,003 \\
\hline 63 & 20,181 & 212 & ,002 \\
\hline 65 & 20,181 & 212 & ,001 \\
\hline 191 & 20,151 & ,213 & ,001 \\
\hline 38 & 19,938 & 223 & ,002 \\
\hline 30 & 19,885 & ,225 & ,001 \\
\hline 61 & 19,741 & 232 & ,002 \\
\hline 64 & 19,683 & 235 & ,002 \\
\hline 221 & 19,618 & 238 & ,002 \\
\hline 56 & 19,538 & 242 & ,002 \\
\hline 164 & 19,532 & ,242 & ,001 \\
\hline 129 & 19,286 & ,254 & ,003 \\
\hline 90 & 19,269 & ,255 & ,002 \\
\hline 134 & 19,100 & ,264 & ,003 \\
\hline 57 & 18,589 & 291 & ,027 \\
\hline 124 & 18,259 & ,309 & ,075 \\
\hline 40 & 18,064 & ,320 & ,115 \\
\hline 218 & 17,971 & ,326 & 124 \\
\hline 207 & 17,628 & ,346 & ,266 \\
\hline 92 & 17,602 & ,348 & ,240 \\
\hline 68 & 17,543 &, 351 & 234 \\
\hline 233 & 17,160 & ,375 & ,462 \\
\hline 2 & 17,077 &, 381 & ,475 \\
\hline 87 & 17,053 & ,382 & 441 \\
\hline 172 & 17,035 &, 383 & ,402 \\
\hline 74 & 17,020 & ,384 & ,363 \\
\hline 89 & 16,848 & 395 & ,447 \\
\hline 104 & 16,821 & 397 & ,417 \\
\hline 39 & $16,45^{2}$ & ,422 & 664 \\
\hline
\end{tabular}

At-Tijaroh : Jurnal Ilmu Manajemen dan Bisnis Islam, Volume 5, Nomor 1 Tahun 2019 http://jurnal.iain-padangsidimpuan.ac.id/index.php/attijaroh 
133 | Analisis Simultan Komitmen Organisasional dan Organizational

Citizenship Behavior Terhadap Kinerja Karyawan

\begin{tabular}{rrrr}
\hline $\begin{array}{c}\text { Observation } \\
\text { number }\end{array}$ & $\begin{array}{c}\text { Mahalanobis } \\
d \text {-squared }\end{array}$ & $\mathrm{p} 1$ & $\mathrm{p} 2$ \\
\hline 142 & 16,391 &, 426 &, 662 \\
208 & 16,391 &, 426 &, 612 \\
169 & 16,370 &, 427 &, 579 \\
223 & 16,332 &, 430 &, 558 \\
\hline
\end{tabular}

Sumber: Data yang Diolah (2019)

\subsubsection{Uji Multikolinearitas}

Analisis terjadinya mutikolinearitas pada sebuah penelitian dapat dilihat melalui hasil output determinan matriks covarians, dimana dikatakan terjadi mutikolinearitas apabila pada hasil output muncul tanda peringatan (warning), sehingga tidak bisa melakukan eksekusi (Ferdinand, 2002). Dalam penelitian ini tidak terdapat tanda peringatan (warning), sehingga model penelitian ini tidak terdapat mutikolinearitas.

\subsubsection{Uji Hipotesis (Analisis Kausalitas)}

Analisis kausalitas dilakukan untuk mengetahui hubungan antar variabel. Pada penelitian ini pengujian kausalitas dapat digunakan untuk mengetahui hubungan yang terjadi antara OCB, komitmen organisasional, dan kinerja karyawan.

Hubungan antar konstruk dapat dilihat dari nilai p-value pada regression weights pada tabel 4.12., dimana jika nilai p-value $\leq 0,05$, maka menunjukan terdapat hubungan yang signifikan antar konstruk. Kemudian, untuk mengetahui besarnya hubungan antar konstruk ditunjukan dengan standarized regression weights pada tabel 4.13.

Tabel 12

Regression weights

\begin{tabular}{|c|c|c|c|c|c|}
\hline & & Estimate & S.E. & C.R. & P Label \\
\hline OCB & $<---\quad \mathrm{KO}$ & ,098 & ,040 & 2,437 & ,015 par_7 \\
\hline $\mathrm{KO}$ & $<---\quad$ OCB & ,363 & ,150 & 2,415 & ,016 Par 16 \\
\hline KK & $<---\quad \mathrm{KO}$ & 162 & ,057 & 2,830 & ,005 par_8 \\
\hline KK & $<---\quad$ OCB & 281 & ,106 & 2,664 & ,oo8 par_9 \\
\hline
\end{tabular}

Sumber: Data yang Diolah (2019)

Tabel 13

Standardized Regression Weights

\begin{tabular}{|c|c|c|}
\hline & & Estimate \\
\hline$\overline{\mathrm{OCB}}$ & $<---\quad \mathrm{KO}$ & ,189 \\
\hline $\mathrm{KO}$ & $<---\quad$ OCB & ,189 \\
\hline KK & $<---\quad \mathrm{KO}$ & 233 \\
\hline KK & $<---\quad$ OCB & ,210 \\
\hline
\end{tabular}

Sumber: Data yang Diolah (2019) 
Berdasarkan tabel 12 dan 13, dapat diketahui bahwa semua variabel independen berpengaruh langsung terhadap kinerja karyawan. Kesimpulan mengenai hasil penelitian terkait dengan hubungan langsung antar variabel tersebut dapat dijelaskan sebagai berikut:

$\mathrm{H}_{1}$ : Komitmen organisasional memiliki pengaruh positif signifikan terhadap OCB Dari tabel 12 diketahui bahwa hubungan antara komitmen organisasional terhadap OCB memiliki p-value sebesar 0,015 ( $\leq$ 0,05), sehingga artinya komitmen organisasional berpengaruh signifikan terhadap $\mathrm{OCB}$, dan $\mathrm{H}_{1}$ diterima. Sedangkan besarnya pengaruh langsung komitmen organisasional terhadap OCB dapat dilihat pada tabel 13, yaitu sebesar 0,189 (positif).

$\mathrm{H}_{2}$ : OCB memiliki pengaruh positif signifikan terhadap komitmen organisasional Dari tabel 4.12. diketahui bahwa hubungan antara OCB terhadap komitmen organisasional memiliki p-value sebesar 0,016 ( $\leq$ 0,05), sehingga artinya OCB berpengaruhsignifikan terhadap komitmen organisasional, dan $\mathrm{H}_{2}$ diterima. Sedangkan besarnya pengaruh langsung OCB terhadap komitmen organisasional dapat dilihat pada tabel 13, yaitu sebesar 0,189 (positif).

$\mathrm{H}_{3}$ : Komitmen organisasional memiliki pengaruh positif signifikan terhadap kinerja karyawan

Dari tabel 12 diketahui bahwa hubungan antara komitmen organisasional terhadap kinerja karyawan memiliki p-value sebesar 0,005 $(\leq 0,05)$, sehingga artinya komitmen organisasional berpengaruh signifikan terhadap kinerja karyawan, dan $\mathrm{H}_{3}$ diterima. Sedangkan besarnya pengaruh langsung komitmen organisasional terhadap kinerja karyawan dapat dilihat pada tabel 4.13., yaitu sebesar 0,233 (positif).

$\mathrm{H}_{4}$ : OCB memiliki pengaruh positif signifikan terhadap kinerja karyawan

Dari tabel 12 diketahui bahwa hubungan antara OCB terhadap kinerja karyawan memiliki p-value sebesar 0,008 ( $\leq 0,05)$, sehingga artinya komitmen organisasional berpengaruh signifikan terhadap $\mathrm{OCB}$, dan $\mathrm{H}_{4}$ diterima. Sedangkan besarnya pengaruh langsung OCB terhadap kinerja karyawan dapat dilihat pada tabel 13, yaitu sebesar 0,210 (positif).

\subsubsection{Pengaruh Tidak Langsung}

Analisis ini memberikan gambaran mengenai adanya pengaruh tidak langsung, dan pengaruh keseluruhan dari masing-masing variabel. Efek tidak langsung (indirect effect) merupakan efek yang muncul dari variabel antara.

Tabel 4.12.

Pengaruh Tidak Langsung (Indirect Effect)

\begin{tabular}{|c|c|c|c|c|c|c|c|}
\hline \multicolumn{4}{|c|}{ Model 1} & & \multicolumn{3}{|c|}{ Model 2} \\
\hline & KO & OCB & KK & & OCB & KO & KK \\
\hline OCB & ,000 & , 000 & ,000 & $\mathrm{KO}$ & , OOO & , & , O०0 \\
\hline KK & , 040 & ,000 & ,000 & KK & ,059 & , & , OOO \\
\hline
\end{tabular}

Dari tabel diatas, dapat diketahui bahwa pengaruh tidak langsung antara variabel komitmen organisasional terhadap kinerja karyawan sebesar o,040. Hasil ini lebih kecil apabila dibandingkan dengan efek langsungnya, yaitu 0,233. Sedangkan pengaruh tidak langsung OCB terhadap kinerja karyawan sebesar 0,059. Hasil ini juga lebih kecil dari efek 


\section{5 | Analisis Simultan Komitmen Organisasional dan Organizational Citizenship Behavior Terhadap Kinerja Karyawan}

langsungnya, yaitu 0,210. Kedua hasil ini menunjukan bahwa variabel OCB tidak menjadi variabel intervening antara komitmen organisasional dengan kinerja karyawan, dan varibel komitmen organisasional juga tidak menjadi variabel intervening antara OCB dengan kinerja karyawan.

\subsection{Pembahasan Hasil Penelitian}

Hasil pengujian kausalitas menunjukkan bahwa komitmen organisasional berpengaruh positif signifikan terhadap OCB. Hal ini sesuai dengan penelitian sebelumnya (Nadim et al., 2016; Sjahruddin et al., 2013; Supriyanto, 2013), dimana hal ini menunjukkan bahwakomitmen organisasional menjadi salah satu faktor penentu dalam memunculkan OCB pada karyawan. Artinya, jika komitmen organisasional tinggi, maka akan menyebabkan tingginya pula OCB dari karyawan. Hasil pengujian juga menunjukkan bahwa OCB berpengaruh positif signifikan terhadap komitmen organisasional, sehingga sesuai dengan hasil penelitian yang dilakukan oleh Nursyamsi (2013), sehingga hal ini bermaknya bahwa OCB menjadi salah satu faktor penentu dalam membentuk komitmen organisasional pada karyawan. Artinya, jika OCB tinggi, maka akan menyebabkan tingginya pula komitmen organisasional dari karyawan.

Hasil pengujian komitmen organisasional terhadap kinerja karyawan juga menunjukkan pengaruh yang positif signifikan. Hal ini sesuai dengan penelitian sebelumnya yang dilakukan oleh Nurmatias (2015) dan Taurisa \& Ratnawati (2012), sehingga jika komitmen organisasional tinggi, maka akan menyebabkan tingginya pula kinerja karyawan. Adapun pengaruh OCB terhadap kinerja karyawan juga menunjukkan hasil yang positif signifikan, dan sesuai dengan beberapa hasil penelitian sebelumnya (Darto, 2014; Harwiki, 2016; Nursyamsi, 2013; Supriyanto, 2013). Temuan ini bermaknajika OCB tinggi, maka akan menyebabkan tingginya pula kinerja karyawan.

Beberapa hasil temuan ini berimplikasi secara manajerial, dimana perusahaan, khususnya P.T. XYZ dituntut untuk meningkatkan profesionalisme dalam mengelola para karyawannya. Sosialisasi mengenai pentingnya komitmen organisasional dan OCB yang dilakukan dengan masif di kalangan karyawan akan mampu menjadi salah satu usaha dari organisasi dalam meningkatkan kinerja karyawan, sehingga memudahkan pencapaian visi dan misi perusahaan.

\section{KESIMPULAN}

Kesimpulan penelitian ini dimaksudkan untuk mempermudah dalam pemahaman mengenai hasil penelitian. Berikut dipaparkan secara singkat mengenai hasil dari penelitian ini komitmen organisasional memiliki pengaruh positif signifikan terhadap OCB sebesar 0,189, dengan signifikansi sebesaro,015, OCB memiliki pengaruh positif signifikan terhadap komitmen organisasional sebesar 0,189, dengan signifikansi sebesar 0,016, komitmen organisasional memiliki pengaruh positif signifikan terhadap kinerja karyawan sebesar 0,233, dengan signifikansi sebesar 0,005, OCB memiliki pengaruh positif signifikan terhadap kinerja karyawan sebesar 0,210, dengan signifikansi sebesar 0,008, OCB sebagai variabel intervening pada hubungan kausalitas antara komitmen organisasional dengan kinerja karyawan tidak memiliki pengaruh signifikan, karena pengaruh tidak langsung komitmen organisasional pada kinerja karyawan $(0,040)$ lebih kecil dibanding pengaruh langsung diantara kedua variabel tersebut $(0,233)$, komitmen organisasional sebagai variabel intervening pada hubungan kausalitas antara OCB dengan kinerja karyawan tidak memiliki 
pengaruh signifikan, karena pengaruh tidak langsung OCBpada kinerja karyawan (0,059) lebih kecil dibanding pengaruh langsung diantara kedua variabel tersebut $(0,210)$.

Berdasarkan hasil penelitian ini yang berimplikasi secara manajerial, P.T. XYZ dituntut untuk meningkatkan profesionalisme dalam mengelola para karyawannya. Sosialisasi mengenai pentingnya komitmen organisasional dan OCB yang dilakukan dengan masif di kalangan karyawan. Selain itu, perusahaan juga mampu mengakomodir faktor-faktor yang dapat meningkatkan kinerja karyawan, komitmen organisasi serta menumbuhkembangkan nilai-nilai OCB dikalangan personal karyawan. Dengan demikian akan memudahkan pencapaian visi, misi dan tujuan perusahaan, baik tujuan jangka pendek maupun tujuan jangka panjang. Untuk penilitian lebih lanjut, disarankan penelitian berikutnya meneliti faktor lain yang berpengaruh terhadap kinerja karyawan, serta faktor-faktor lain yang mempengaruhi komitmen organisasional dan OCB. Terlebih di era Revolusi Industri 4.0 yang perubahannya serba cepat. Selain itu, teknik pengumpulan data hendaknya lebih diperdalam dengan melakukan observasi dan wawancara.

\section{DAFTAR PUSTAKA}

Abdullah, \& Arisanti, H. (2010). Pengaruh budaya organisasi, komitmen organisasi dan akuntabilitas publik terhadap kinerja organisasi. Jurnal Ekonomi Dan Bisnis, 9(2), 118-134.

Ajzen, I. 1988. Attitudes, traits, and actions: Dispositional prediction of behavior in personality and social psychology. In L. Berkowitz (Ed), Advances in experimental social psychology, New York: Academic Press, Vol. 20, pp. 1-63.

Ajzen, I. 1991. The Theory of Planned Behavior, Organizational Behavior and Human Decision Processes, vol. 50, no. 2, pp. 179-211.

Allen, N. J., \& Meyer, J. P. (1990). The measurement and antecedents of affective, continuance and normative commitment to the organization, 1-18.

Annisa, \& Zulkarnain. (2013). Komitmen terhadap Organisasi Ditinjau dari Kesejahteraan Psikologis Pekerja. INSAN, 15(01), 54-62.

Bateman, T., \& Organ, D. (1983). Job Satisfaction and the Good Soldier: The Relationship Between Affect and Employee 'Citizenship. Academy of Management Journal, 26(4), 587595. https://doi.org/https://doi.org/10.2307/255908

Christine, W., Oktorina, M., \& Mula, I. (2010). Pengaruh Konflik Pekerjaan dan Konflik Keluarga sebagai Interverning Variabel (Studi pada Dual Career Couple di Jabotabek). Jurnal Manajemen Dan Kewirausahaan, 12(2), 121-132.

Darto, M. (2014). Peran Organizational Citizenship Behavior (OCB) dalam Peningkatan Kinerja Individu di Sektor Publik: Sebuah Analisis Teoritis dan Empiris. Jurnal Analisa, 1O(1), 1034 .

Ellinger, A. E., Casey, C., Musgrove, F., Ellinger, A. D., Bachrach, D. G., \& Wang, Y. (2013). Influences of organizational investments in social capital on service employee commitment and performance. Journal of Business Research Influences, 66, 1124-1133. https://doi.org/10.1016/j.jbusres.2012.03.008

Fayyaz, H. (2014). Effect of Task Oriented and Relational Leadership Style on Employee Performance; Moderating Impact of Communicator Competence. Journal of Marketing and Consumer Research, 3, 1-9. 


\section{7 | Analisis Simultan Komitmen Organisasional dan Organizational Citizenship Behavior Terhadap Kinerja Karyawan}

Ferdinand, A. (2002). Structural Equation Modeling dalam Penelitian Manajemen. Semarang: Badan Penerbit UNDIP.

Ferdinand, A. (2014). Metode Penelitian Manajemen (5th ed.). Semarang: Badan Penerbit UNDIP.

Fishbein, M., and Ajzen, I. 1975. Belief, attitude, intention, and behavior: An introduction to theory and research, Reading, MA: Addison.Wesley. Harrison, D.A., Mykytyn, P.P. and Riemenschneider, C.K. 1997. Executive decision about adoption of information technology in small business: theory and empirical tests. Information Systems Research, Vol. 8 No. 2, pp. 71-95.

Ghozali, I. (2011). Model Persamaan Struktural Konsep dan Aplikasi dengan program AMOS 19.o. Semarang: Badan Penerbit Universitas Diponegoro.

Hair, J. F., Black, W. J., Babin, B. J., \& Anderson, R. E. (2010). Multivariate Data Analysis: A Global Perspective. New Jersey: Pearson Prentice Hall.

Handoko, H. (1989). Manajemen Personalia \& Sumberdaya Manusia (2nd ed.). Yogyakarta: BPFE Yogyakarta.

Harwiki, W. (2016). The Impact of Servant Leadership on Organization Culture, Organizational Commitment, Organizational Citizenship Behaviour (OCB) and Employee Performance in Women Cooperatives. In 3rd Global Conference on Business and Social Sciences-2015 (Vol. 219, pp. 283-290). https://doi.org/10.1016/j.sbspro.2016.04.032

Hasibuan. (2011). Manajemen Sumber Daya Manusia: Edisi Revisi (Bumi Aksar). Jakarta.

Hayati, K., \& Caniago, I. (2012). Islamic Work Ethic: The Role of Intrinsic Motivation, Job Satisfaction, Organizational Commitment and Job Performance. In International Congress on Interdisciplinary Business and Social Science 2012 (Vol. 65, pp. 272-277). The Authors. https://doi.org/10.1016/j.sbspro.2012.11.122

Hulin, C. (1998). Adaptation, persistence, and commitment in organizations (Handbook of industrial and organizational psychology, Vol. 2). Mumbai: Jaico Publishing.

Kuncoro, M. (2009). Metode Riset untuk Bisnis dan Ekonomi (3rd ed.). Jakarta: Penerbit Erlangga.

Mangkunegara, A., \& Anwar, P. (2001). Manajemen Sumber Daya Perusahaan (3rd ed.). Bandung: Remaja Rosdakarya.

Mathis, R. L., \& Jackson, J. H. (2002). Manajemen Sumber Daya Manusia (Buku 1). Jakarta: Salemba Empat.

Nadim, M., Hassan, M. M., Abbas, S., \& Naveed, A. (2016). The Role of Organizational Commitment and Perceived Organizational Support in Promoting Organizational Citizenship Behavior. PEOPLE: International Journal of Social Sciences, 2(3), 54-67. https://doi.org/https://doi.org/10.20319/pijss.2016.23.5467

Nizam, S., Sarah, S., \& Osman, A. (2016). The Effect of Islamic Work Ethics on Organizational Commitment. In 7th International Economics \& Business Management Conference (Vol. 35, pp. 582-590). Elsevier B.V. https://doi.org/10.1016/S2212-5671(16)00071-X

Novita, Sunuharjo, B. S., \& Ruhana, I. (2016). Pengaruh Kepuasan Kerja dan Komitmen Organisasional terhadap Kinerja Karyawan (Studi pada PT. Telekomunikasi Indonesia, Tbk

At-Tijaroh : Jurnal Ilmu Manajemen dan Bisnis Islam, Volume 5, Nomor 1 Tahun 2019 http://jurnal.iain-padangsidimpuan.ac.id/index.php/attijaroh 
Witel Jatim Selatan, Malang). Jurnal Administrasi Bisnis (JAB), 34(1), 38-46.

Nurmatias, F. (2015). Pengaruh Etika Kerja Islam, Komitmen Organisasi terhadap Kinerja Karyawan di Institut Agama Islam Tafaqquh Fiddin Dumai. Jurnal Tamaddun Ummah, 1(1), 1-14.

Nursyamsi, I. (2013). Organizational Citizenship Behavior dan Pemberdayaan terhadap Komitmen Organisasi serta Dampaknya terhadap Kinerja Karyawan. Jurnal Keuangan Dan Perbankan, 17(3), 488-498.

Robbins, S., \& Judge, T. (2008). Perilaku Organisasi. (R. Widyaningrum, Ed.) (12th ed.). Jakarta: Salemba Empat.

Simamora, H. (2001). Manajemen Sumber Daya Manusia (3rd ed.). Yogyakarta: STIE YKPN.

Sjahruddin, H., Armanu, Sudiro, A., \& Normijati. (2013). Organizational Justice, Organizational Commitment and Trust in Manager as predictor of Organizational Citizenship Behavior. Interdisciplinary Journal of Contemporary Research in Business, 4(12), 133-141.

Skarlicki, D., \& Latham, G. (1996). Increasing citizenship behavior within a labor union: A test of organizational justice theory. Journal of Applied Psychology, 81, 161-169.

Supriyanto, A. S. (2013). Role of Procedural Justice, Organizational Commitment and Job Satisfaction on Job Performance: The Mediating Effects of Organizational Citizenship Behavior. International Journal of Business and Management, 8(15). https://doi.org/https://doi.org/10.5539/ijbm.v8n15p57

Taurisa, C. M., \& Ratnawati, I. (2012). Analisis Pengaruh Budaya Organisasi dan Kepuasan Kerja terhadap Komitmen Organisasional dalam Meningkatkan Kinerja Karyawan (Studi pada PT. Sido Muncul Kaligawe Semarang). Jurnal Bisnis Dan Ekonomi (JBE), 19(2), 170-187.

Teresia, N., \& Suyasa, P. T. Y. (2008). Komitmen Organisasi dan Organizational Citizenship Behavior pada Karyawan Call Centre di PT. X. Phronesis: Jurnal Ilmiah Psikologi Industri Dan Organisasi, 1O(2), 154-169.

Werner, P. 2004. Reasoned Action and Planned Behavior, in S.J. Peterson and T.S. Bredow (eds), Middle Range Theories: Application to Nursing Research, Lippincott Williams and Wilkins, Philadelphia, pp. 125-147

Yiing, L. H., \& Zaman, K. (2009). The moderating effects of organizational culture on the relationships between leadership behaviour and organizational commitment and between organizational commitment and job satisfaction and performance. Leadership \& $\begin{array}{llll}\text { Organization Development } & \text { Journal, } & \text { 53-86. }\end{array}$ https://doi.org/10.1108/01437730910927106

Zhang, D. (2011). Organisational Citizenship Behaviour. 